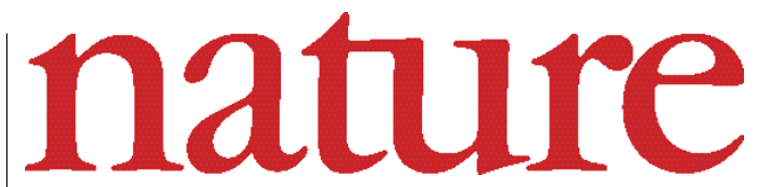

\title{
From red peril to red tape
}

Tight US customs controls on microbiological materials could threaten foreign research collaborations. Especially at risk are attempts to integrate Russia's former bioweapons scientists into the mainstream.

W hen Thomas Butler of Texas Tech University in Lubbock was arrested in January, a clear message was sent out to US microbiologists working with foreign collaborators: stick to the letter of the law - or else. Butler was working to develop new antibiotics to treat plague. But the project is in disarray after he was accused of various offences, including smuggling vials containing the plague bacterium, Yersinia pestis, collected in Tanzania, into the United States on commercial flights.

Butler's case has yet to come to trial. But other researchers who work on similar pathogens admit privately that they have been tempted to bend the rules that Butler is accused of flouting. Thanks to strict customs controls introduced under the ongoing 'war on terrorism', it has become all but impossible to bring samples of pathogenic bacteria and viruses into the United States through official channels.

Those trying to initiate collaborations with former members of the Soviet bioweapons establishment are especially frustrated. They must fight customs authorities in both countries to get even basic equipment sent to Russia, and wrestle with immigration officials to invite collaborators back to their labs. Their efforts are hampered by mutual mistrust between former Cold War opponents: while US officials are worried by tales of endemic Russian corruption, their Russian counterparts seem to view each visiting Western scientist as a potential spy (see page 678).

But these collaborations stand to benefit both sides. The US government is currently investing enormous sums in research to counter the threat of bioterrorism. For the scientists charged with this task, it makes sense to reach out to the labs that once served as the research powerhouses of the world's largest biowarfare programme. On the other side, Russia's pressing problems with epidemics of infectious diseases, including AIDS and tuberculosis, cry out for the skills of its former military microbiologists to be turned to peaceful purposes.

Things must change if these collaborations are to continue. Russian officials must learn to welcome Western scientists into their labs. And the United States needs to review its sometimes overzealous customs and immigration controls. In the wake of 11 September 2001, and the anthrax attacks that followed, clamping down on the import of hazardous biological material was sensible. But risks need to be put into perspective. It is arguable that the current expansion of domestic US labs working on biodefence poses a greater threat of proliferation than the transfer of samples between the United States and Russia.

If Western officials are serious about countering bioweapons proliferation, they should also start thinking more broadly. Building capacity in microbiology outside the secret network of labs that housed the Soviet Union's biowarfare programme is important, to help integrate the labs' denizens into the broader scientific community of the former Soviet states. One positive example is a European Union-funded project under which scientists in Oslo and London helped to analyse data on samples of fleas and rodents collected by the Anti-Plague Research Institute in Almaty, Kazakhstan, over some 50 years. The project has improved understanding of the transmission of plague in central Asia.

There are a few encouraging signs. US government officials are reportedly talking to the Russian Academy of Sciences in the hope of getting it interested in working with the former bioweapons labs. But integrating former bioweapons scientists into the international scientific community seems to be a low priority for politicians on both sides. Until legislators realize the sizeable benefits to both Russia and the rest of the world, scientists working on such collaborations will be faced with an unenviable choice: let their research stagnate, or risk breaking the law.

\section{Debate, what debate?}

The UK government is squandering the chance to canvass public opinion on one of the hottest controversies in science.

$\mathrm{H}$ ow do you condense the views of the public on genetically modified (GM) crops into a single document? One innovative, if experimental, solution is to try to spark public debate among community groups across the country. In Britain, this effort got under way last week. It is supposed to inform the decision, to be made in the autumn, on whether to allow commercial planting of the crops.

Six set-piece debates are being held in cities around Britain in the first two weeks of June. These are meant to act as springboards for discussions at local level. Questionnaires and recordings from the events should generate more detailed insights into public thinking than opinion polls can provide - helping to reveal how people have come to hold the views that they express (see page 672).

It's a laudable idea. But one problem has become painfully clear: most of the public don't know they are invited, for reasons that aren't hard to discern. Over the past three years, the Netherlands (population 16 million) and New Zealand (population 4 million) have conducted similar programmes to assess opinion on genetically modified crops,

each investing some four times the sum allotted in Britain (population 60 million). This penny-pinching has restricted advertising, and turnouts at the first debates have been limited to a few hundred, with the majority already having a vested interest in the subject.

Members of the panel organizing the debate, which includes representatives from industry and academia, as well as experts on public consultation, claim that they were given too little time to set up the debate. The panel's first meeting was last September; the government expects the results to be complete by mid-July.

This sorry state of affairs will have two consequences. The opportunity to test a consultation process that could be applied to many other scientific controversies - from the alleged environmental hazards posed by nanotechnology to the ethics of embryonic stemcell research - could be squandered. Worse, negative media coverage may leave the British people to assume that the government has already made up its mind on transgenic agriculture, and simply isn't interested in their views. 